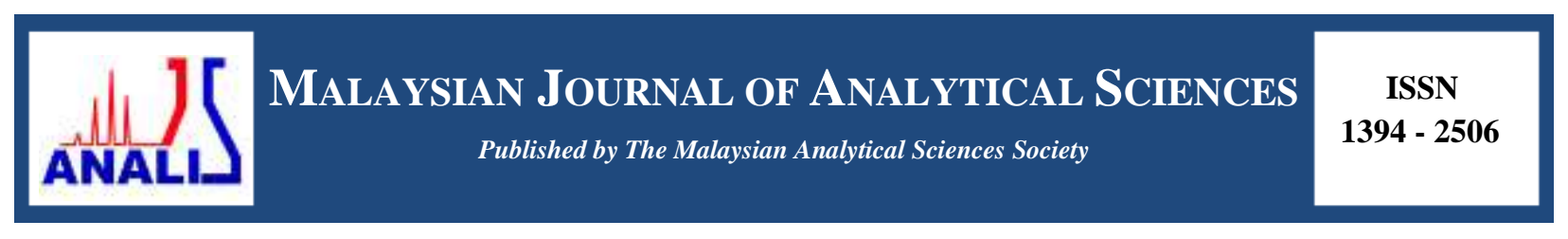

\title{
EPOXIDATION SYNTHESIS OF LINOLEIC ACID FOR RENEWABLE ENERGY APPLICATIONS
}

\author{
(Penghasilan Asid Linoleik Berepoksidasi untuk Penggunaan Tenaga yang Diperbaharui) \\ Bashar Mudhaffar Abdullah ${ }^{1}$, Rahimi M. Yusop ${ }^{2 *}$, Jumat Salimon ${ }^{2}$, Darfizzi Derawi ${ }^{2}$, Waled Abdo Ahmed ${ }^{2}$ \\ ${ }^{I}$ Clinical Investigation Centre, \\ University Malaya Medical Centre, 13th Floor Main Tower, Lembah Pantai, 59100 Kuala Lumpur, Malaysia \\ ${ }^{2}$ Oleochemistry Programme, School of Chemical Sciences \& Food Technology, Faculty of Science and Technology, \\ Universiti Kebangsaan Malaysia, 43600 UKM Bangi, Selangor, Malaysia \\ *Corresponding author: rahimi@ukm.edu.my
}

Received: 3 August 2015; Accepted: 4 November 2015

\begin{abstract}
Monoepoxidation linoleic acid (MEOA) has advantages for industrial applications. MEOA was synthesized using immobilized Candida antarctica lipase (Novozym $435^{\circledR}$ ). At optimum conditions, higher yield $(82.14 \%$ ) and medium oxirane oxygen content, OOC (4.91\%) of MEOA were predicted at $15 \mu \mathrm{L}$ of $\mathrm{H}_{2} \mathrm{O}_{2}, 120 \mathrm{mg}$ of Novozym $435^{\circledR}$ and 7 hours of reaction time. Fourier Transform Infrared Spectroscopy (FTIR) spectra of the MEOA showed monoepoxide group at $820 \mathrm{~cm}^{-1}$. ${ }^{1} \mathrm{H} \mathrm{NMR}$ analysis confirmed the monoepoxide group at $2.92-3.12 \mathrm{ppm}$ while the monoepoxide signals of ${ }^{13} \mathrm{C}$ NMR appear at $54.59-$ $57.29 \mathrm{ppm}$. LC-MS analysis shows that of MEOA gives $\mathrm{m} / \mathrm{z}$ at 296.22 as final product. MEOA exhibited good pour point (PP) of $-41{ }^{\circ} \mathrm{C}$. Flash point (FP) of MEOA increased to $128^{\circ} \mathrm{C}$ comparing with $115^{\circ} \mathrm{C}$ of linoleic acid (LA). In a similar fashion, viscosity index (VI) for LA was 224 generally several hundred centistokes (cSt) more viscous than MEOA 130.8. MEOA was screened to measure their oxidative stability (OT) which was observed at $168{ }^{\circ} \mathrm{C}$. It is evident that increasing the hydrogen peroxide amount has a strong effect on the reaction kinetics; however, a large excess of hydrogen peroxide results in accumulation of peracid in the final product.
\end{abstract}

Keywords: linoleic acid, Novozym $435^{\circledR}$, self-epoxidation, renewable energy

\section{Abstrak}

Mono-pengepoksidaan asid linoleik (MEOA) mempunyai kelebihan untuk aplikasi industri. MEOA telah disintesis menggunakan Candida Antartika lipase (Novozym 435 ()) pegun. Pada keadaan yang optimum, peratus hasil MEOA sebanyak $82.1 \%$ dengan kandungan oksigen oksirana (OOC) sebanyak $4.91 \%$ diperolehi dengan menggunakan $15 \mu \mathrm{L} \mathrm{H}_{2} \mathrm{O}_{2}, 120 \mathrm{mg}$ Novozym 435 ® dan 7 jam tindak balas. Analisis ${ }^{1} \mathrm{H}$ NMR mengesahkan kumpulan terepoksida pada $2.92-3.12$ ppm manakala isyarat ${ }^{13} \mathrm{C}$ NMR menunjukkan bacaan pada $54.59-57.29 \mathrm{ppm}$. Analisis LC-MS menunjukkan bahawa MEOA memberikan m/z 296.22 sebagai produk akhir. MEOA menunjukkan takat tuang yang baik pada suhu $-41^{\circ} \mathrm{C}$. Takat kilat MEOA meningkat pada suhu $128^{\circ} \mathrm{C}$ berbanding pada suhu $115^{\circ} \mathrm{C}$ oleh asid linoleik (LA). Dalam keadaan yang sama, kebiasaanya VI untuk LA pada 224 beberapa ratus sentistok (cSt) lebih likat daripada MEOA 130.8. MEOA mempunyai kestabilan oksidatif pada suhu $168^{\circ} \mathrm{C}$. MEOA berpotensi untuk dijadikan sebagai produk pertengahan dalam aplikasi tenaga keterbaharuan.

Kata kunci: asid linoleik, Novozym $435 \AA$, pengepoksidaan, tenaga diperbaharui 


\section{Bashar Mudhaffar et al: EPOXIDATION SYNTHESIS OF LINOLEIC ACID FOR RENEWABLE ENERGY APPLICATIONS}

\section{Introduction}

Bio-renewable materials, such as plant oils and unsaturated fatty acid derivatives, have recently received increasing attention as a means of addressing environmental and economic concerns. Epoxidized oils are currently produced by the epoxidation of plant oils such as soybean, linseed oil [1] and Jatropha curcas seed oil [2].

Although the monoepoxidation of linoleic acid or its methyl ester has been carried out repeatedly in the past, it was only recently that a study of positional selectivity in the monoepoxidation of methyl linoleate was reported [3]. There are several methods to epoxidize the double bonds of unsaturated fatty acids, such as Prileshajev monoepoxidation reaction. In this reaction, a peracid from a short or long chain fatty acid and hydrogen peroxide $\left(\mathrm{H}_{2} \mathrm{O}_{2}\right)$ under strong acidic conditions is used as the oxidizing agent. The peracid can either be added to the reaction mixture or is formed in situ, the latter being preferred due to safety reasons. The presence of the strong acid in the reaction mixture, however, causes the formation of side products, such as vicinal diols, estolides and other dimers. Although the careful choice of the peracid and the reaction conditions can help to minimize the epoxide loss, the selectivity of industrial monoepoxidation of unsaturated fatty acids rarely exceeds $80 \%$ [4].

The effect of reaction parameters on lipase-mediated chemo-enzymatic monoepoxidation of linoleic acid (LA) has been investigated [4] $\mathrm{H}_{2} \mathrm{O}_{2}$ was found to have the most significant effect on the reaction rate and degree of epoxidation. An excess of $\mathrm{H}_{2} \mathrm{O}_{2}$ with respect to the amount of double bonds was necessary in order to yield total conversion within a short time period, as well as at temperatures above $50{ }^{\circ} \mathrm{C}$ to compensate for $\mathrm{H}_{2} \mathrm{O}_{2}$ decomposition. The reaction rate also increased by increasing the hydrogen peroxide concentration (between 10 and $50 \mathrm{wt}-\%$ ), albeit at the expense of enzyme inactivation. LA was completely epoxidized when used at a concentration of $0.5-2 \mathrm{M}$ in toluene at $30{ }^{\circ} \mathrm{C}$, while in a solvent-free medium, the reaction was not complete due to the formation of a solid or a highly viscous oily phase, creating mass transfer limitations. Increasing the temperature up to $60{ }^{\circ} \mathrm{C}$ also improved the rate of epoxide formation. The monoepoxidation of methyl linoleate was examined using transition metal complexes as catalysts [5]. With a catalytic amount of MTO (4 mol\%) and pyridine, methyl linoleate was completely epoxidized by aqueous $\mathrm{H}_{2} \mathrm{O}_{2}$ within $4 \mathrm{~h}$. Longer reaction times $(6 \mathrm{~h})$ were needed with 1 mol\% catalyst loading. Manganese tetraphenylporphyrin chloride was found to catalyze the partial epoxidation of methyl linoleate. A monoepoxidized species was obtained as the major product (63\%) after 20 hours.

Objective of this study was attempted to improve the efficiency of monoepoxidation under milder conditions that minimize the formation of byproducts. Chemo-enzymatic monoepoxidation uses the immobilized lipase from Candida Antarctica (Novozym $435^{\circledR}$ ) to catalyze conversion of fatty acids to peracids with $60 \%$ hydrogen peroxide. The fatty acid is then self-epoxidized in an intermolecular reaction. The lipase is remarkably stable under the reaction conditions and can be recovered and reused 15 times without loss of activity. Different lipase catalysts have been studied, of which Novozym $435^{\circledR}$, a commercial preparation of Candida Antarctica lipase B, has been shown to be the most effective so far. Most of the investigations have involved dilution of the substrate in organic solvent. Recently, lipase mediated monoepoxidation in a solvent-free medium has also been reported [4]. LA, bearing two $\mathrm{C}=\mathrm{C}$ double bonds, is one of the major components in Jatropha curcas seed oil. This study focuses on the impact of various reaction parameters on the monoepoxidation process, with the aim to determine optimal reaction conditions with regard to reaction efficiency and enzyme stability using D-optimal design. LA was used as the model substrate.

\section{Experimental procedure}

\section{Materials and Methods}

The enzymatic monoepoxidation was carried out using Novozym $435^{\circledR}$, a commercial catalyst made up of lipase, from Candida Antarctica, immobilized on a polyacrylate resin [4]. Table 1 shows the different ratios of hydrogen peroxide $\left(\mathrm{H}_{2} \mathrm{O}_{2}\right)$, different amounts of enzyme and different reaction times using D-optimal design. Three factors (variables) including hydrogen peroxide $\left(\mu \mathrm{L}, \mathrm{X}_{1}\right)$, enzyme $\left(\mathrm{mg}, \mathrm{X}_{2}\right)$ and reaction time $\left(\mathrm{h}, \mathrm{X}_{3}\right)$ were performed for 18 experiments at the same experimental conditions.

In a typical chemo-enzymatic monoepoxidation of linoleic acid, 9(12)-10(13)-monoepoxy 12(9)-octadecanoic acid (MEOA), the LA (1.4 g) was dissolved in $10 \mathrm{~mL}$ toluene and the lipase was added. After stirring for 15 min, 15-20 $\mu \mathrm{L}$ of $30 \% \mathrm{H}_{2} \mathrm{O}_{2}$ was added and every 15 min the addition was repeated for $6-8$ hours. Afterwards the lipase was removed by filtration, the mixture was washed with water to remove excess $\mathrm{H}_{2} \mathrm{O}_{2}$ and the organic phase was then 
dried over anhydrous sodium sulphate; the solvent was evaporated in a vacuum rotary evaporator. The oxirane ring content (OOC \%) [6], yield\% and iodine value (IV) [7] were measured. The FTIR, ${ }^{1} \mathrm{H},{ }^{13} \mathrm{C}$ NMR and LC-MS were analyzed and the physicochemical properties of the product were studied [7].

Table 1. Independent variables and their levels for D-optimal design of the monoepoxidation reaction

\begin{tabular}{lcccc}
\hline Independent variables & & \multicolumn{3}{c}{ Coded Levels } \\
\cline { 2 - 5 } & & $\mathbf{- 1}$ & $\mathbf{0}$ & $\mathbf{+ 1}$ \\
\hline $\mathrm{H}_{2} \mathrm{O}_{2}(\mu \mathrm{L})$ & $X_{1}$ & 15 & 17.5 & 20 \\
Enzyme $(\mathrm{mg})$ & $X_{2}$ & 80 & 100 & 120 \\
Time $(\mathrm{h})$ & $X_{3}$ & 6 & 7 & 8 \\
\hline
\end{tabular}

\section{Experimental design and statistical analysis}

To explore the effect of the operation variables on the response in the region of investigation, a D-optimal design at three levels was performed. $\mathrm{H}_{2} \mathrm{O}_{2}\left(\mu \mathrm{L}, X_{1}\right)$, amount of enzyme $\left(\mathrm{mg}, X_{2}\right)$ and reaction time $\left(\mathrm{h}, X_{3}\right)$ were selected as independent variables. The range of values and coded levels of the variables are given in Table 1. A quadratic polynomial regression model was assumed for predicting $\mathrm{Y}$ variables. The model proposed for each response of $\mathrm{Y}$ was:

$$
\mathrm{Y}=\beta_{0}+\sum \beta_{\mathrm{i}} \mathrm{x}_{\mathrm{i}}+\sum \beta_{\mathrm{ii}} \mathrm{x}_{\mathrm{i}}^{2}+\sum \sum \beta_{\mathrm{ij}} \mathrm{x}_{\mathrm{i}} \mathrm{x}_{\mathrm{j}}
$$

Where $\beta_{0} ; \beta_{\mathrm{i}} ; \beta_{\mathrm{ii}}$ and $\beta_{\mathrm{ij}}$ are constant, linear, square and interaction regression coefficient terms, respectively, and $x_{i}$ and $x_{j}$ are independent variables. The Minitab software version 14 (Minitab Inc., USA) was used for multiple regression analysis, analysis of variance (ANOVA), and analysis of ridge maximum of data in the response surface regression (RSREG) procedure. The goodness of fit of the model was evaluated by the coefficient of determination $R^{2}$ and the analysis of variance (ANOVA). Response surfaces and contour plots were developed using the fitted quadratic polynomial equations obtained from RSREG analysis and holding the independent variables with the least effect on the response at two constant values and changing the levels of the other two variables [8].

\section{Reaction and mechanism of the monoepoxidation linoleic acid}

\section{Results and Discussion}

Figure 1 demonstrates the scheme for the monoepoxidation reaction of LA (MEOA). MEOA results in a mixture of two monoepoxides (cis-9, 10-epoxy 12c- 18:1 and cis-12, 13 epoxy 9c- 18:1) with yield\% of $75.82 . \mathrm{H}_{2} \mathrm{O}_{2}$ is an important reactant for the formation of peracids from fatty acids; hence, the influence of its amount on the monoepoxidation reaction was studied.

The addition of $\mathrm{H}_{2} \mathrm{O}_{2}$ solution to the reaction medium (toluene with LA) leads to the formation of two distinct phases, an organic phase and an aqueous phase show in Figure 2. The Novozym $435^{\circledR}$, being adsorbed on a hydrophobic carrier, is mainly present in the organic phase. $\mathrm{H}_{2} \mathrm{O}_{2}$ will be partitioned in both the aqueous and the organic phases, with the concentration being higher in the aqueous phase (Figure 2) due to consumption of $\mathrm{H}_{2} \mathrm{O}_{2}$ for peracid formation in the organic phase.

The ratio of $\mathrm{H}_{2} \mathrm{O}_{2}$ to $\mathrm{H}_{2} \mathrm{O}$ tends to decrease slightly in organic phase. Hence, for the reaction to proceed optimally, it is essential that the transport of the $\mathrm{H}_{2} \mathrm{O}_{2}$ from the aqueous phase to the organic phase is faster than its utilization in the enzymatic reaction [4]. 


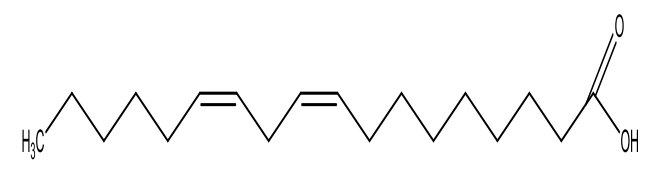

(1)

[Novozym $435^{\circledR}$ ]
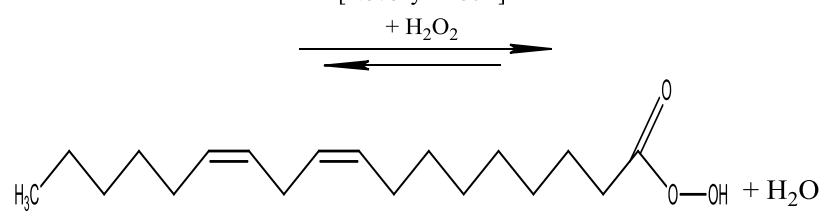

(2)

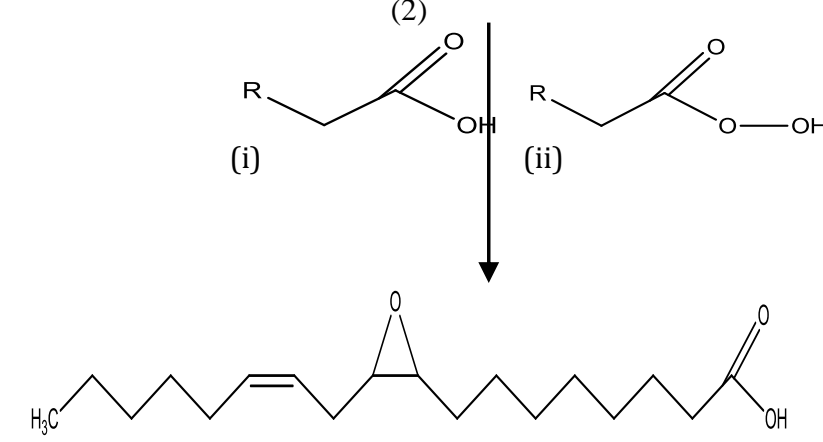

(3a)

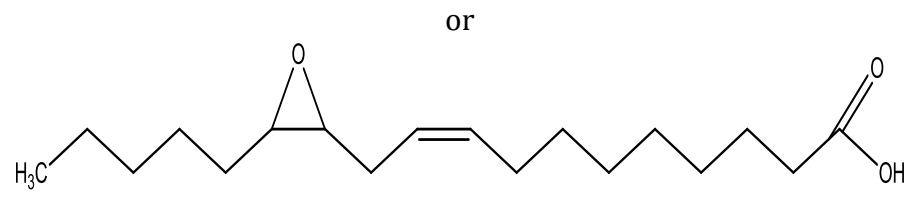

(3b)

Figure 1. Chemo-enzymatic monoepoxidation of LA

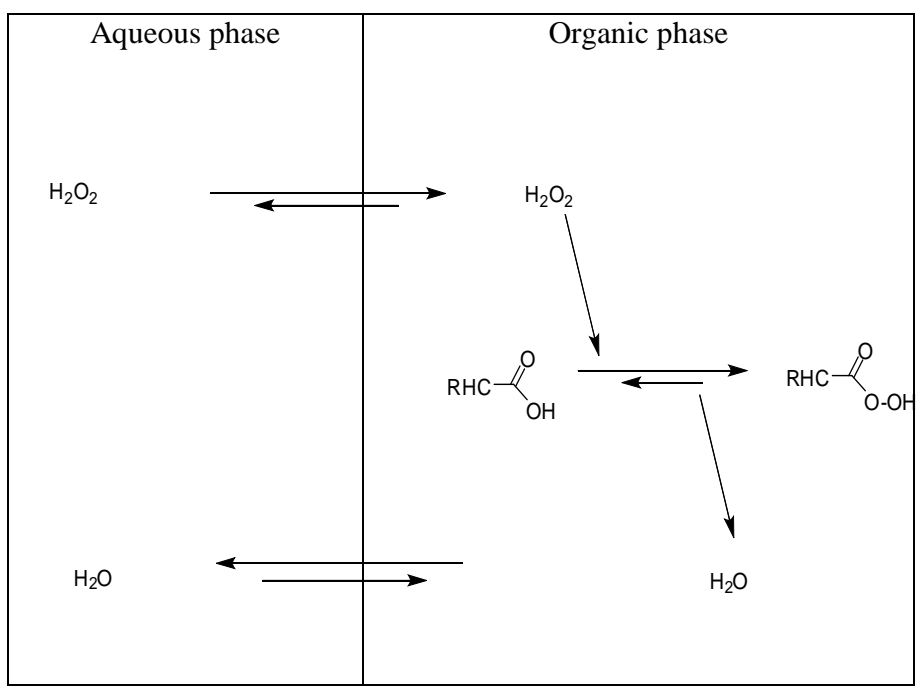

Figure 2. Transport of $\mathrm{H}_{2} \mathrm{O}_{2}$ and water in an organic-water biphasic system 
The reaction synthesis was determined by varying amounts of $\mathrm{H}_{2} \mathrm{O}_{2}(15,17.5$ and $20 \mu \mathrm{L})$, which was added every $15 \mathrm{~min}$, the addition was repeated 24 times. The different amounts of Novozym $435^{\circledast}(80,100$ and $120 \mathrm{mg})$ and different times $\left(6,7\right.$ and 8 hours) also have been used. A stoichiometric excess of the required amount of the $\mathrm{H}_{2} \mathrm{O}_{2}$ was used to compensate for its possible decomposition by light and temperature. Epoxide contains oxygen as one of the ring atoms. The mechanism of converting the peracid to epoxide involves one-step and the relative stereochemistry of the alkene is maintained in the epoxide [7]. The mechanism is shown schematically in Figure 3.

The double bond acts as the nucleophile with the $\pi$-electrons attacking the peracid oxygen. In one-step, the oxygenoxygen bond breaks and the electrons shift over to form a new $\pi$-bond between oxygen and carbon. This causes the $\pi$-bond of the existing carbonyl to break and those electrons attack the terminal hydrogen. Finally, the electrons from the $\mathrm{O}-\mathrm{H}$ bond, which is breaking, add to the alkene carbon to form the three-member ring epoxide [9].

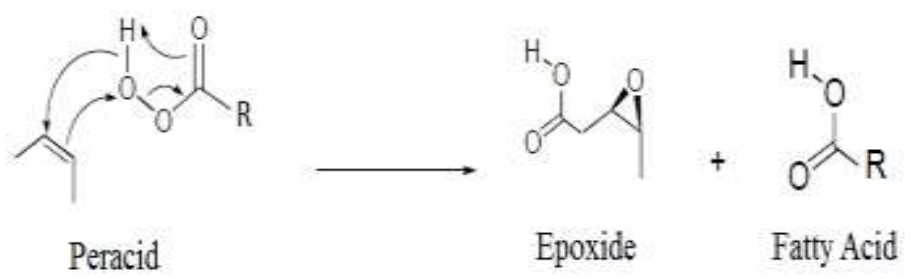

Figure 3. Mechanism of converting peracid to epoxide

\section{Effect of process parameters and statistical analysis}

This study demonstrates the application of the proposed response surface methodology (RSM) framework for the optimization of MEOA by using Novozym $435^{\circledR}$ catalytic monoepoxidation process. Hence, the knowledge about the process is relatively limited, and the design is used to obtain 18 design points within the whole range of three factors for experiments.

The designs and the responses yield percentage of MEOA $\left(Y_{1}\right)$, oxirane oxygen content percentage (OOC, $\left.Y_{2}\right)$ and iodine value (IV $\mathrm{mg} / \mathrm{g}, Y_{3}$ ) are given in Table 2. Following the reaction experiments, the response surface is estimated by D-optimal design. Table 2 shows that the yield\% of MEOA of $Y_{l}$ increased to (82.14 \%) while OOC\% of $Y_{2}$ (4.91) and IV of $Y_{3}$ (77.65) which is considerable compared to the theoretical OOC $t$ (9.02) and initial iodine value $\mathrm{IV}$ 。 $(157.35 \mathrm{mg} / \mathrm{g})$. The conversion percentage of the MEOA is $81.35 \%$. Subsequent experiments were performed using different amounts of $\mathrm{H}_{2} \mathrm{O}_{2} 15,17.5$ and $20 \mu \mathrm{L}$ for every $1.4 \mathrm{gm}$ of LA in one single step. As seen in Table 2, there is a clear increase in the reaction rate (OOC percentage) and decrease iodine value (IV $\mathrm{mg} / \mathrm{g}$ ) with increasing $\mathrm{H}_{2} \mathrm{O}_{2}$ amount. With $15 \mu \mathrm{L}$, monoepoxidation was achieved at $7 \mathrm{~h}$ using $120 \mathrm{mg}$ Novozym $435^{\circledR}$.

The quadratic regression coefficients obtained by employing the least squares method technique to predict quadratic polynomial models for the yield percentage of MEOA $\left(Y_{1}\right)$, OOC percentage $\left(Y_{2}\right)$ and IV $\mathrm{mg} / \mathrm{g}\left(Y_{3}\right)$ have been explained. For the yield percentage of MEOA $\left(Y_{l}\right)$, the linear term of Novozym $435^{\circledR}$ catalyst amount $\left(X_{2}\right)$, quadratic terms of $\mathrm{H}_{2} \mathrm{O}_{2}\left(X_{11}\right)$ and Novozym $435^{\circledR}$ catalyst amount $\left(X_{22}\right)$ were significant $(\mathrm{p}<0.05)$. The interaction between $\mathrm{H}_{2} \mathrm{O}_{2}\left(X_{11}\right)$ and Novozym $435^{\circledR}$ catalyst amount $\left(X_{12}\right)$, and the interaction between $\mathrm{H}_{2} \mathrm{O}_{2}\left(X_{11}\right)$ and reaction time $\left(X_{13}\right)$ were significant $(\mathrm{p}<0.05)$, while its quadratic term of reaction time $\left(X_{33}\right)$ was highly significant $(\mathrm{p}<0.01)$. Highly significant terms $(\mathrm{p}<0.01)$ of OOC\% $\left(Y_{2}\right)$ and IV $\mathrm{mg} / \mathrm{g}\left(Y_{3}\right)$ for the $\mathrm{H}_{2} \mathrm{O}_{2}\left(X_{1}\right)$ were linear. The linear term of IV $\mathrm{mg} / \mathrm{g}$ for the reaction time $\mathrm{h}\left(X_{3}\right)$ was significant $(\mathrm{p}<0.05)$.

The lack of fit $F$-value for all the responses shows that the lack of fit was not significant $(p>0.05)$ relative to the pure error. This indicates that all the models predicted for the responses were adequate. Regression models for data on responses $Y_{1}, Y_{2}$, and $Y_{3}$, were highly significant $(p<0.01)$ with satisfactory $R^{2}(0.90,0.69$ and 0.79 , respectively). However, the $R^{2}$ for $Y_{2}(0.69)$ was lower although the model was significant. Table 3 summarizes the analysis of variance (ANOVA) of all the responses of this study. 
Table 2. D-optimal design arrangement and responses for MEOA

\begin{tabular}{|c|c|c|c|c|c|c|c|c|c|}
\hline \multirow{2}{*}{$\begin{array}{l}\text { Run } \\
\text { No. }\end{array}$} & \multicolumn{3}{|c|}{ Coded Independent } & \multicolumn{6}{|c|}{$\underline{\text { Responses }}$} \\
\hline & $\begin{array}{c}\mathbf{H}_{2} \mathbf{O}_{2} \\
\left(X_{I}\right)\end{array}$ & $\begin{array}{c}\text { Catalyst }^{\mathrm{a}} \\
\left(X_{2}\right)\end{array}$ & $\begin{array}{c}\text { Time } \\
\left(X_{3}\right)\end{array}$ & $\begin{array}{c}\text { Yield } \\
\left(Y_{l}, \%\right)\end{array}$ & $\begin{array}{c}\text { OOC } \\
\left(Y_{2}, \%\right)\end{array}$ & $\begin{array}{c}\mathrm{RCO} \\
(\%)\end{array}$ & $\begin{array}{c}\text { IV } \\
\left(Y_{3}, \mathbf{m g} / \mathbf{g}\right)\end{array}$ & $\underset{(\%)}{\mathbf{X}}$ & SE \\
\hline 1 & 20 & 80 & 8 & 76.57 & 6.17 & 68.40 & 37.81 & 76.37 & 0.89 \\
\hline 2 & 17.5 & 80 & 7 & 88.57 & 5.48 & 60.75 & 58.95 & 62.53 & 0.97 \\
\hline 3 & 17.5 & 100 & 8 & 72.14 & 7.54 & 83.59 & 32.22 & 79.52 & 1.05 \\
\hline 4 & 20 & 80 & 6 & 72.28 & 6.4 & 70.95 & 40.98 & 73.95 & 0.95 \\
\hline 5 & 20 & 120 & 7 & 54.71 & 5.94 & 65.85 & 64.32 & 59.12 & 1.11 \\
\hline 6 & 20 & 120 & 6 & 60.28 & 7.88 & 87.36 & 30.87 & 80.38 & 1.08 \\
\hline 7 & 15 & 120 & 8 & 73.57 & 5.48 & 60.75 & 53.24 & 66.16 & 0.91 \\
\hline 8 & 20 & 80 & 7 & 81.42 & 5.37 & 59.53 & 56.32 & 64.20 & 0.92 \\
\hline 9 & 15 & 100 & 7 & 75.68 & 5.02 & 55.65 & 74.64 & 52.56 & 1.05 \\
\hline 10 & 18.7 & 100 & 7 & 85.28 & 5.71 & 63.30 & 49.17 & 68.75 & 0.92 \\
\hline 11 & 20 & 100 & 7 & 81.14 & 6.05 & 67.06 & 42.72 & 72.85 & 0.92 \\
\hline 12 & 15 & 120 & 6 & 70.78 & 4.57 & 50.66 & 76.48 & 51.39 & 0.98 \\
\hline 13 & 15 & 100 & 6 & 65.93 & 3.65 & 40.46 & 96.43 & 38.71 & 1.00 \\
\hline 14 & 15 & 120 & 7 & 82.14 & 4.91 & 54.43 & 77.65 & 57.64 & 0.94 \\
\hline 15 & 17.5 & 120 & 8 & 59.28 & 6.74 & 74.72 & 36.37 & 76.63 & 0.97 \\
\hline 16 & 20 & 100 & 6 & 72.85 & 6.51 & 72.17 & 39.76 & 74.73 & 0.90 \\
\hline 17 & 15 & 80 & 8 & 77.14 & 4.34 & 48.11 & 83.85 & 46.71 & 1.03 \\
\hline 18 & 17.5 & 100 & 6 & 80.85 & 3.77 & 41.79 & 87.09 & 44.65 & 0.93 \\
\hline
\end{tabular}

Notes: OOC, oxirane oxygen content; RCO, relative percentage conversion to oxirane; $I V$, iodine value; $X$, conversion to double bond; SE, oxirane oxygen selectivity; ${ }^{a}$ catalyst Novozym $435^{\circledR}$ ( $\mathrm{mg}$ )

Table 3. Analysis of variance (ANOVA) for all the responses of MEOA

\begin{tabular}{llrrrrrl}
\hline & Source & $\boldsymbol{D f}$ & $\begin{array}{r}\text { Sum of } \\
\text { squares }\end{array}$ & $\begin{array}{r}\text { Mean } \\
\text { square }\end{array}$ & $\begin{array}{c}\boldsymbol{F} \\
\text { value }\end{array}$ & Prob>F & \\
\hline$Y_{1}$ & Model & 9 & 1298.00 & 144.22 & 8.22 & 0.0034 & Significant \\
& Residual & 8 & 140.36 & 17.55 & & & \\
& Lack-of-fit & 3 & 144.05 & 48.02 & 0.69 & 0.5763 & Not significant \\
& Pure error & 5 & 3.69 & 0.738 & & & \\
$Y_{2}$ & Model & 3 & 13.62 & 4.54 & 6.74 & 0.0048 & Significant \\
& Residual & 14 & 9.43 & 0.67 & & & \\
& Lack-of-fit & 3 & 1.43 & 0.48 & 0.66 & 0.5956 & Not significant \\
& Pure error & 11 & 8.00 & 0.727 & & & \\
$Y_{3}$ & Model & 3 & 4423.70 & 598.002 & 8.18 & 0.002 & Significant \\
& Residual & 14 & 2522.67 & 180.19 & & & \\
& Lack-of-fit & 3 & 734.74 & 244.91 & 1.51 & 0.2672 & Not significant \\
& Pure error & 11 & 1787.93 & 162.539 & & & \\
\hline
\end{tabular}


These results suggest that linear effect of $\mathrm{H}_{2} \mathrm{O}_{2}$ is the primary determining factor for MEOA. The $\mathrm{H}_{2} \mathrm{O}_{2}$ had a very large effect on the results of their monoepoxidation study. The final equations in terms of actual factors are:

$$
\begin{aligned}
& Y_{1}=+87.53-2.82 X_{I}-4.50 X_{2}-0.14 X_{3}-9.06 X_{I}^{2}-5.43 X_{2}^{2}-9.81 X_{3}^{2}-9.74 X_{I} X_{2}-7.14 X_{I} X_{3}-7.80 X_{2} X_{3} \\
& Y_{2}=+5.59+1.00 X_{I}+0.58 X_{2}+0.51 X_{3}-0.37 X_{I}^{2}-0.099 X_{2}^{2}+0.31 X_{3}^{2}-0.22 X_{I} X_{2}-0.55 X_{1} X_{3}-0.27 X_{2} X_{3} \\
& Y_{3}=+56.24-18.82 X_{I}-8.91 X_{2}-10.57 X_{3}+8.06 X_{I}^{2}+4.15 X_{2}^{2} 4.41 X_{3}^{2}+11.59 X_{I} X_{2}+10.81 X_{1} X_{3}+5.42 X_{2} X_{3}
\end{aligned}
$$

The significant interaction variables in the fitted models were chosen as the axes (amount of $\mathrm{H}_{2} \mathrm{O}_{2} ; X_{1}$, amount of Novozym $435^{\circledR} ; X_{2}$ and reaction time; $X_{3}$ ) for the response surface plots. The relationships between independent and dependent variables are shown in the three-dimensional representation as response surfaces. Figures 4 to 6 are the Design plots for all the responses. In the MEOA, performing the technique using a low amount of $\mathrm{H}_{2} \mathrm{O}_{2}$ would give the desired OOC\% of MEOA, as shown in Figure 5, while IV (Figure 6) was higher at this condition. As shown in Figures 5 and 6, increasing the amount of $\mathrm{H}_{2} \mathrm{O}_{2}$ led to an increase in the OOC percentage and a reduction of IV. The relationships between the parameters and MEOA were linear or almost linear. High OOC percentage could be obtained by using a high amount of $\mathrm{H}_{2} \mathrm{O}_{2}$ at high reaction time. Experimental variables should be carefully controlled in order to recover a medium percentage of MEOA of interest with reasonable yield [4].

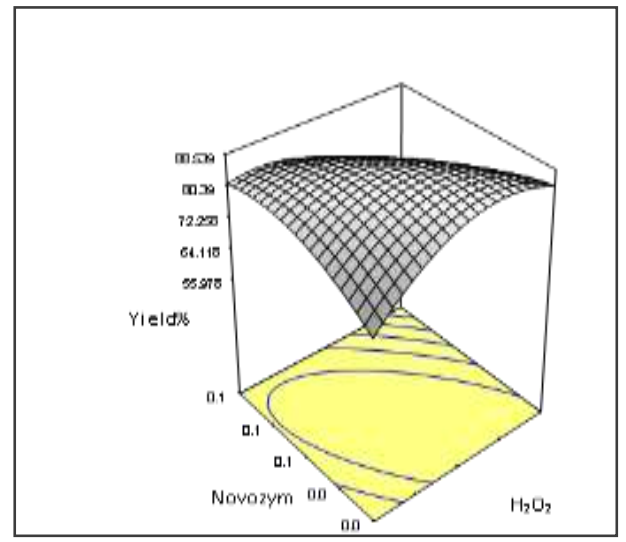

Figure 4. Response surface for the effect of the $\mathrm{H}_{2} \mathrm{O}_{2}\left(X_{1}\right.$, $\mu \mathrm{L})$ and catalysts Novozym $435^{\circledR}\left(X_{2}, \mathrm{mg}\right)$ on the yield $\%$ of MEOA

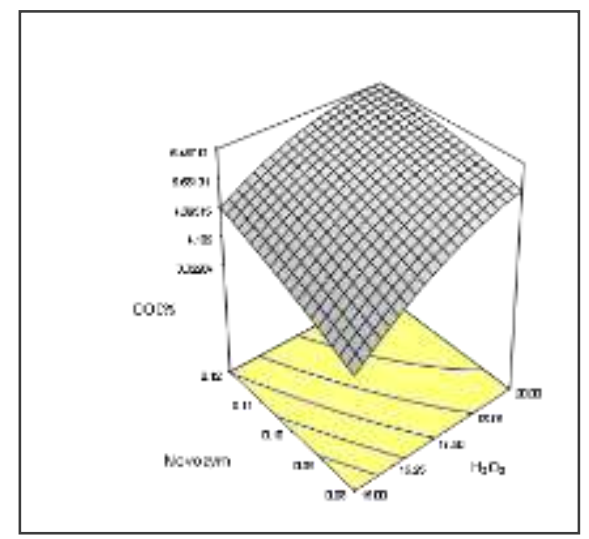

Figure 5. Response surface for the effect of the $\mathrm{H}_{2} \mathrm{O}_{2}$ $\left(X_{1}, \mu \mathrm{L}\right)$ and catalysts Novozym $435^{\circledR}\left(X_{2}\right.$, $\mathrm{mg}$ ) on the OOC\% of MEOA

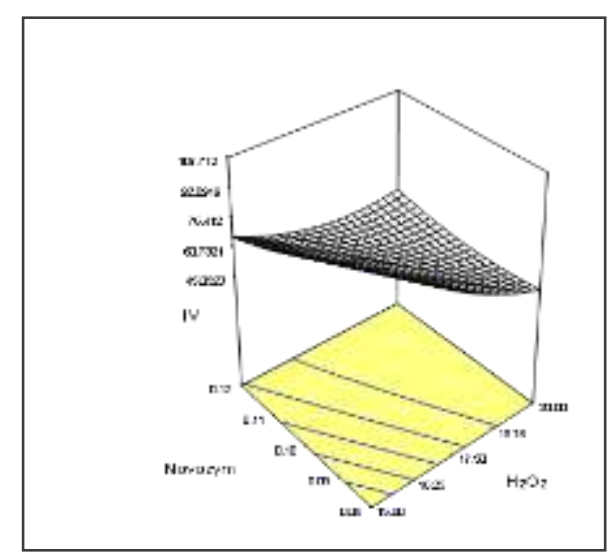

Figure 6. Response surface for the effect of the $\mathrm{H}_{2} \mathrm{O}_{2}\left(X_{1}, \mu \mathrm{L}\right)$ and catalysts Novozym $435^{\circledR}\left(X_{2}, \mathrm{mg}\right)$ on the IV mg/g of MEOA 


\section{Bashar Mudhaffar et al: EPOXIDATION SYNTHESIS OF LINOLEIC ACID FOR RENEWABLE ENERGY APPLICATIONS}

The optimum conditions of the experiment to obtain a higher yield percentage of MEOA and medium OOC percentage were predicted at amount of $\mathrm{H}_{2} \mathrm{O}_{2}$ of $15 \mu \mathrm{L}$, catalyst Novozym $435^{\circledR}$ of $120 \mathrm{mg}$ and $7 \mathrm{~h}$ reaction time. At this condition, the yield percentage of MEOA was $82.14 \%, 4.91 \%$ of OOC and $77.65 \mathrm{mg} / \mathrm{g}$ of IV. Reconfirmation of the optimal condition experiment was carried out at three replicate. While full epoxidation was observed within $10 \mathrm{~h}$ using $30 \mu \mathrm{L}$ of $\mathrm{H}_{2} \mathrm{O}_{2}$, increasing the $\mathrm{H}_{2} \mathrm{O}_{2}$ amount used for the reaction results in the increasing formation of peracid. In the state of MEOA, the amount of peracids accumulated is not significant [10], due to the chemical reaction in which they are consumed is very fast. The reaction could indicate that with a high amount of catalyst, the utilization of $\mathrm{H}_{2} \mathrm{O}_{2}$ is so fast that the epoxidation of the double bonds does not keep pace with the formation of peracids. However, once all the double bonds are epoxidized, the remaining peracid is not consumed [4]. The observed value was reasonably close to the predicted value, as shown in Figures $7-9$ respectively.

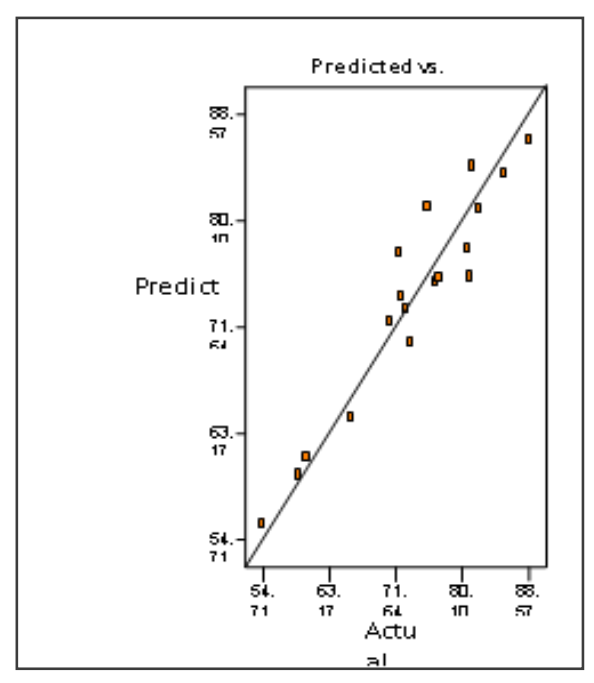

Figure 7. Predicated vs. actual plot of $Y_{1}$

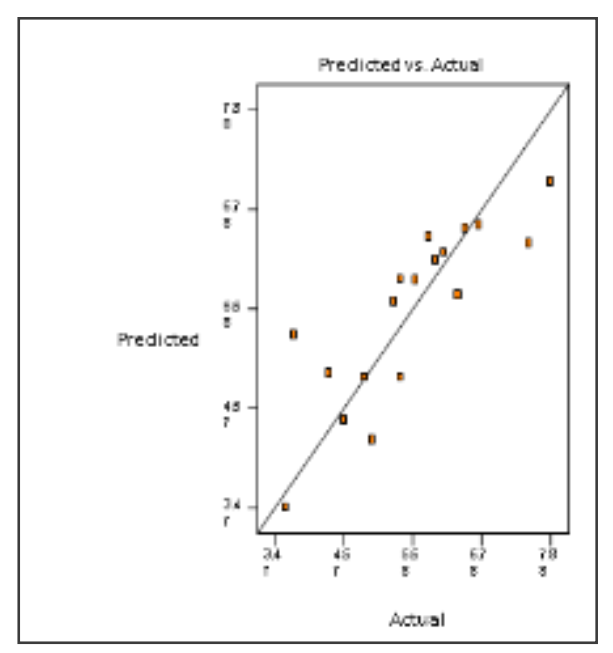

Figure 8. Predicated vs. actual plot of $Y_{2}$

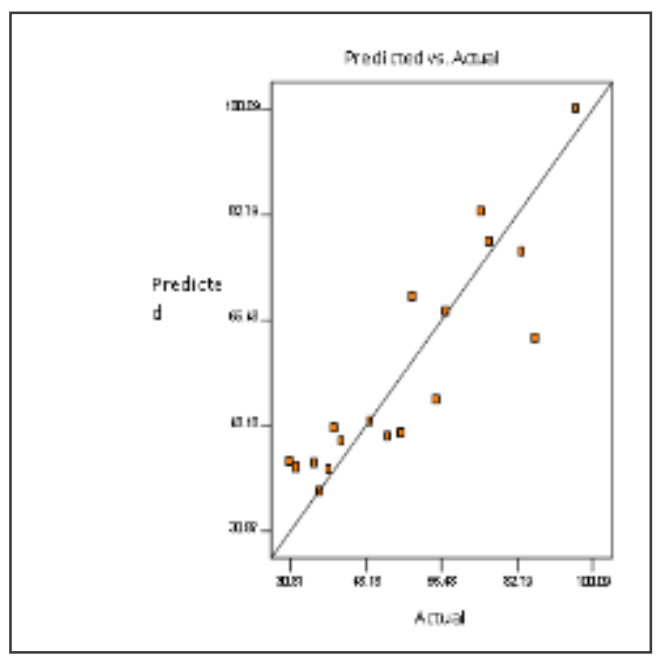

Figure 9. Predicated vs. actual plot of $Y_{3}$ 


\section{FTIR analysis of MEOA}

In order to prove the presence of the oxirane ring of MEOA, the final product was tested by FTIR. The oxirane ring of MEOA can be detected at $820 \mathrm{~cm}^{-1}$ [9]. For the carboxylic acid carbonyl functional groups $(\mathrm{C}=\mathrm{O})$, FTIR spectrum showed absorption bands of LA and MEOA at 1719 and $1711 \mathrm{~cm}^{-1}$, respectively, while stretching vibration peak of $\mathrm{C}=\mathrm{C}$ can be detected at wavenumber $3009 \mathrm{~cm}^{-1}$ [11]. Peaks at $2927-2856 \mathrm{~cm}^{-1}$ indicate the $\mathrm{CH}_{2}$ and $\mathrm{CH}_{3}$ scissoring of LA and MEOA. FTIR spectrum also shows absorption bands at $722,723 \mathrm{~cm}^{-1}$ for $(\mathrm{C}-\mathrm{H})$ group vibration.

\section{${ }^{1} \mathrm{H}$ and ${ }^{13} \mathrm{C}$ NMR Analysis of MEOA}

The ${ }^{1} \mathrm{H}$ NMR spectroscopy shows the main signal assignments in LA, MEOA and di-epoxide LA. The ${ }^{1} \mathrm{H}$ NMR spectra for the products show some of the key features for a typical (-CH-O-CH-) at about $2.92-3.12 \mathrm{ppm}$ of MEOA and about $2.99-3.13 \mathrm{ppm}$ of di-epoxide LA. The distinguishable groups are the protons of the terminal methyl of the fatty acid chain. The signals at $0.88-0.86 \mathrm{ppm}$ indicate the methylene group $\left(-\mathrm{CH}_{3}\right)$ of LA, which also appear in MEOA $0.86-0.88 \mathrm{ppm}$ and di-epoxide LA $0.88-0.92 \mathrm{ppm}$ next to the terminal methyl $\left(-\mathrm{CH}_{2}\right)$ at $1.30-2.06 \mathrm{ppm}$ of LA, $1.29-2.03$ of MEOA and $1.34-1.75 \mathrm{ppm}$ of di-epoxide LA. However, the methane proton signals $(-\mathrm{CH}=\mathrm{CH}-)$ were shifted upfield at about $5.35-5.36 \mathrm{ppm}$ of LA and $5.38-5.49 \mathrm{ppm}$ of MEOA while they disappeared in di-epoxide LA [12]. The signal at $7.27 \mathrm{ppm}$ referred to the solvent $\mathrm{D}_{2} \mathrm{O}$ for LA, MEOA and diepoxide LA [7].

The ${ }^{13} \mathrm{C}$ spectroscopy shows the main signals assignment of the LA. The signals at $180.49 \mathrm{ppm}$ refer to the carbon atom of the carbonyl group (carboxylic acid). The signals at $128.27-130.38 \mathrm{ppm}$ refers to the unsaturated carbon atoms (olefinic carbons); $24.86-29.79 \mathrm{ppm}$ due to methylene carbon atoms in fatty acid moieties of LA [13]. The results confirm the oxirane ring of MEOA $54.59-57.29 \mathrm{ppm}$ and di-epoxide LA at about 54.61 - $57.32 \mathrm{ppm}$. Indeed, it appears that the signals were present in the MEOA, as four peaks of roughly equal intensity (132.89, $132.72,130.15$, and $124.02 \mathrm{ppm}$ ) were observed in the alkenic carbon region in the ${ }^{13} \mathrm{C}-\mathrm{NMR}$ spectrum, [5], while they had disappeared in the di-epoxide LA.

The ${ }^{13} \mathrm{C}$-NMR spectra indicate the existence of the carbonyl group (carboxylic acid) in their structure MEOA $179.32 \mathrm{ppm}$ and di-epoxide LA at about $178.79 \mathrm{ppm}$. The other distinctive signals were aliphatic carbons MEOA at about $22.69-29.38 \mathrm{ppm}$ and di-epoxide LA at about $22.77-29.44 \mathrm{ppm}$, which are common for these types of compounds [14]. The signals at $76.91-77.23 \mathrm{ppm}$ refer to the solvent $\mathrm{D}_{2} \mathrm{O}$ for LA, MEOA and di-epoxide LA [6].

\section{Physicochemical Characteristics}

This approach is used to study the low temperature flow behavior of fatty acids by monoepoxide ring. MEOA increased the pour point (PP) to $15{ }^{\circ} \mathrm{C}$ significantly comparing with LA at $-2{ }^{\circ} \mathrm{C}$. It can be assumed that the presence of the oxirane ring has a tendency to form crystalline structures that make it semi solid at low temperature through uniform stacking of the 'bend' epoxy ring [9]. Flash point (FP) is another important factor in determining how well oil will behave as a potential biolubricant. FP is often used as a descriptive characteristic of oil fuel, and it is also used to describe oils that are not normally used as fuels. FP refers to both flammable oils and combustible oils. Although there are various international standards for defining each, most agree that oils with a flash point of less than $43^{\circ} \mathrm{C}$ are flammable, while those having a FP above this temperature are combustible [7]. The FP of MEOA, which increased to $128{ }^{\circ} \mathrm{C}$ compared with $115{ }^{\circ} \mathrm{C}$ of $\mathrm{LA}$, which means the result agrees with the various international standards. The efficiency of the biolubricant in reducing friction and wear is greatly influenced by its viscosity. Generally, the least viscous biolubricant that still forces the two moving surfaces apart is desired. If the biolubricant is too viscous, it will require a large amount of energy to move; if it is too thin, the surfaces will rub and friction will increase. The viscosity index highlights how the viscosity of a biolubricant changes with variations in temperature. The best oils (with the highest VI) will not vary much in viscosity over such a temperature range, and, therefore, will perform well throughout. In MEOA, the decreased viscosity index (VI) of 130.8 of MEOA is the result of less double bonds [7].

The ability of a substance to resist oxidative degradation is another important characteristic of biolubricants. Therefore, MEOA was screened to measure their oxidation stability using PDSC through the determination of OT. 
PDSC is an effective method for measuring oxidation stability of oleochemicals in an accelerated mode [15]. The OT is the temperature at which a rapid increase in the rate of oxidation is observed at a constant, high pressure (200 psi). A high OT would suggest high oxidation stability of the material. OT was calculated from a plot of heat flow (W/g) versus temperature that was generated by the sample upon degradation and by definition. In this study, the OT of MEOA at $168^{\circ} \mathrm{C}$ was higher compared to $\mathrm{LA}$ at $159^{\circ} \mathrm{C}$, indicating that the epoxy function either reduces the abstractibility of $\alpha$-hydrogens or quenches the oxidation process [16].

\section{Liquid Chromatography Mass Spectroscopy for the MEOA}

Formed upon partial LA and MEOA were confirmed the liquid chromatography mass spectroscopy detection (LCMS). The ion source was operated in the negative mode to produce $[M-H]^{-}$precursor ions, which are prone to charge-remote fragmentation [4]. LC-MS analysis shows that of LA and MEOA gives $\mathrm{m} / \mathrm{z}$ as 280.2335 and 296.2278 (Figure 10). LC-MS spectra obtained upon charge-remote fragmentation are usually straightforward to interpret and have been widely used for structural determination of fatty acids and related ester compounds [17].

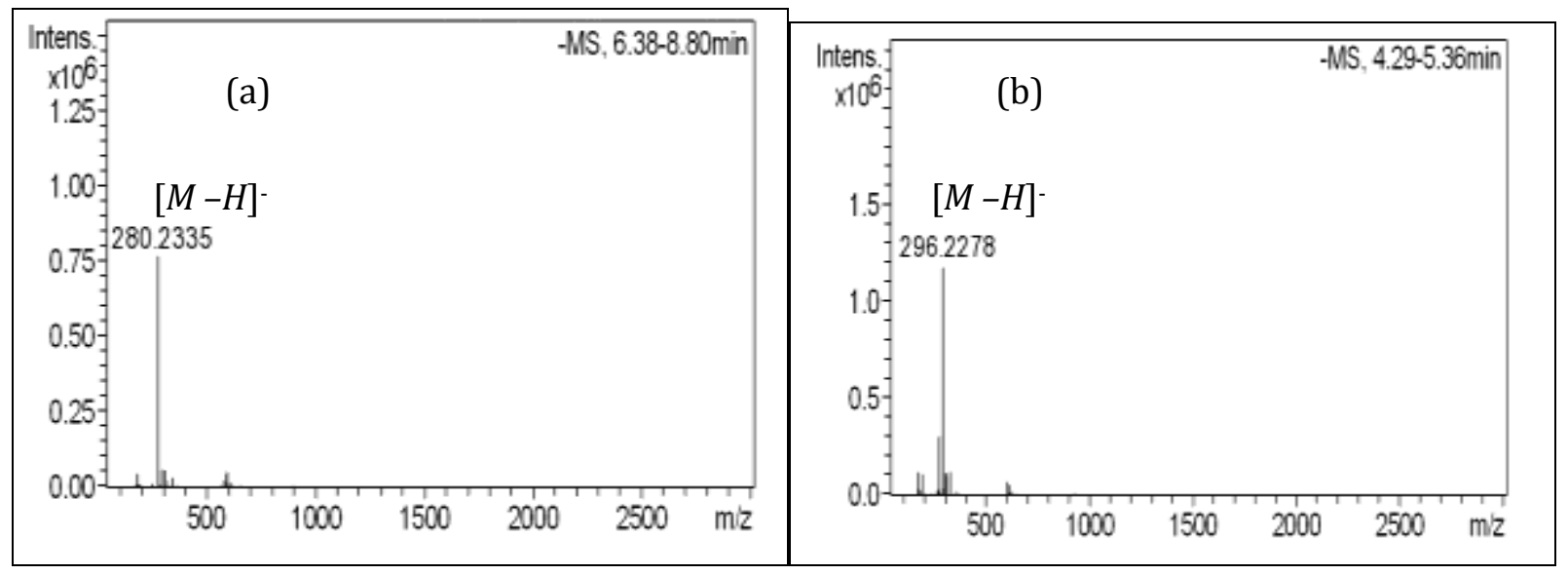

Figure 10. LC-MS analysis of LA (a) and MEOA (b)

\section{Conclusion}

It is evident that $\mathrm{H}_{2} \mathrm{O}_{2}$ is the most critical parameter influencing the chemo-enzymatic monoepoxidation reaction. Increasing the $\mathrm{H}_{2} \mathrm{O}_{2}$ amount has a strong effect on the reaction kinetics; however, a large excess of $\mathrm{H}_{2} \mathrm{O}_{2}$ results in the accumulation of peracid in the final product. At optimum conditions, a higher yield percentage of 82.14 and medium oxirane oxygen content OOC percentage of 4.91 and IV of $77.65 \mathrm{mg} / \mathrm{g}$ were predicted at $15 \mu \mathrm{L} \mathrm{of} \mathrm{H}_{2} \mathrm{O}_{2}$, $120 \mathrm{mg}$ of Novozym 435, and $7 \mathrm{~h}$ of reaction time. The conversion percentage of the MEOA is $81.35 \%$. The MEOA exhibited high PP of $15^{\circ} \mathrm{C}$. In a similar fashion, VI for LA was 224 generally several hundred centistokes more viscous than that MEOA (130.8).

\section{Acknowledgement}

We thank UKM and the Ministry of Science and Technology for research grant UKM-OUP-MI-2011, GGPM-2014033 and DPP-2014-058.

\section{References}

1. Ruesch, M. and Warwel, S. (1999). Complete and partial epoxidation of plant oils by lipase-catalyzed perhydrolysis. Industrial Crops and Products, 9: 125 - 132.

2. Meyer, P-P., Techaphattana, N., Manundawee, S., Sangkeaw, S., Junlakan, W. and Tongurai, C. (2008). Epoxidation of soybean oil and Jatropha oil. Thammasat International Journal of Science Technology, 13: 1 5. 
3. Ferrari, M., Ghisalberti, E. L., Pagnoni, U. M. and Pelizzoni, F. (1968). Monoepoxidation of methyl linoleate: $( \pm)$-methyl vernolate and ( \pm )-methyl coronarate. Journal of the American Oil Chemists' Society, 45: 649 - 651.

4. Orellana-Coca, C., Camocho, S., Adlercreutz, D., Mattiasson B. and Hatti-Kaul, R. (2005). Chemo-enzymatic epoxidation of linoleic acid: parameters influencing the reaction. European Journal of Lipid Science Technology, 107: $864-870$.

5. Du, G., Tekin, A., Hammond, E. G. and Woo, L. K. (2004). Catalytic epoxidation of methyl linoleate. Journal of the American Oil Chemists' Society, 81: 477 - 480.

6. Siew, W. L., Tang, T. S. and Tan, Y. A. (1995). PORIM test methods. Volume 1. Palm Oil Research Institution of Malaysia.

7. Salimon, J., Salih, N. and Abdullah, B. M. (2011). Improvement of physicochemical characteristics of monoepoxide linoleic acid ring opening for biolubricant base oil. Journal of Biomedicine and Biotechnology, 2011: $1-8$.

8. Salimon, J., Abdullah, B. M. and Salih, N. (2012). Selectively increasing of polyunsaturated (18:2) and monounsaturated (18:1) fatty acids in Jatropha curcas seed oil by crystallization using D-optimal design. Chemistry Central Journal, 2012: 6: 65 - 80.

9. Zubrick, J.W. (2000). The Organic chem lab survival manual, 5th edition, Wiley \& Sons, Inc., New York.

10. Warwel, S. and Klaas, M.R.G. (1995). Chemo-enzymatic epoxidation of unsaturated carboxylic acids. Journal of Molecular Catalysis B: Enzymatic, 1: 29 - 35.

11. Socrates, G. (2001). Infrared and Raman characteristic group frequencies: Tables and charts. $3^{\text {rd }}$ ed. John Wily \& Sons Ltd. Chichester, England.

12. Hwang, H-S. \& Erhan, S.Z. (2006). Synthetic lubricant basestocks from epoxidezed soybean oil and Guerbet alcohols. Industrial Crops and Products, 23: 311 - 317.

13. Abdullah, B. M. and Salimon, J. (2009). Physicochemical characteristics of Malaysian rubber (Hevea brasiliensis) seed oil. European Journal of Scientific Research, 31: 437 - 445.

14. Doll, K. M., Sharma, B. K. and Erhan, S. Z. (2007). Synthesis of branched methyl hdroxy stearates including an ester from bio-based levulinic acid. Industrial and Engineering Chemistry Research, 46: 3513 - 3519.

15. Zhang, Y.Y., Ren, T. H., Wang, H. D. and Yi, M. R. (2004). A comparative study of phenol-type antioxidants in methyl oleate with quantum calculations and experiments. Lubrication Science, 16: 385 - 392.

16. Samuelsson, J. and Johansson M. (2001). A Study of fatty acid methyl esters with epoxy or alkyne functionalities. Journal of the American Oil Chemists' Society, 78: 1191 - 1196.

17. Hsu, F-F. and Turk, J. (2004). Studies on sulfatides by quadrupole ion-trap mass spectrometry with electrospray ionization: structural characterization and the fragmentation processes that include an unusual internal galactose residue loss and the classical charge-remote fragmentation. Journal of the American Society for Mass Spectrometry, 15: 536 - 546. 